\title{
Silkworm as an animal infection model for the screening of environmental, clinical and veterinary pathogens
}

\author{
Rahman $\mathrm{A}^{1}$, Sultana $\mathrm{M}^{1}$, Uddin $\mathrm{MA}^{2}$, Malek $\mathrm{MA}^{1}$, Hossain $\mathrm{MA}^{1}$ \\ ${ }^{1}$ Department of Microbiology, University of Dhaka, Dhaka, Bangladesh, ${ }^{2}$ Bangladesh Sericulture \\ Research and Training Institute, Rajshahi, Bangladesh. \\ Email: hossaina@du.ac.bd
}

\begin{abstract}
Silkworm, Bombyx mori, has passive immunity and can be infected by pathogenic bacteria. Therefore, it can be used as a robust bacterial infection model for screening of pathogenic isolates from various sources. In this work, 11 environmental, clinical and veterinary isolates were screened for pathogenicity using silkworm larvae by injecting bacterial suspension through their dorsal surface and observing response. Experimental conditions were established by using Bacillus thuringiensis SW_R_F_1, Escherichia coli O157:H7, E. coli DH5 $\alpha$ and $0.6 \%$ saline. Nine out of 11 isolates were detected pathogenic after screening. The biochemical and genomic analysis of the nine test isolates confirmed their pathogenicity. The $\mathrm{LD}_{50}$ of Pseudomonas aeruginosa $47 \mathrm{D}$ and

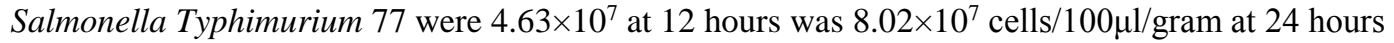
respectively. These results indicated that silkworm exhibits differential pathological response for pathogenic and nonpathogenic bacteria, and can be used as an alternative to animal model for screening diverse isolates.
\end{abstract}

Key words: Silkworm larvae, animal model, pathogenic bacteria, non-pathogen, pathogen screening

\section{Introduction}

Animal model for toxicology testing to drug discovery, ${ }^{1,2}$ is a prominent issue all over the world for various reasons, offers a biological system in which researchers can test their hypothesis in vivo and can investigate phenomenon under study. ${ }^{2}$ Animal model can also be employed for microbial pathogenicity testing. With the recent advent of isolation of novel microorganisms, ${ }^{3}$ it is essential to challenge their ability of infect within biological system to understand host-pathogen interactions. ${ }^{4}$ Although use of mammalian models in bacterial infection study is well established, it is often a difficult job when a large number of bacterial strains need to be tested because this requires a large number of animals to be challenged. It seems costly, time consuming, requires complex experimental procedure and set-up as well as moral conflict from animal rights point of view. Silkworm, Bombyx mori, an invertebrate animal excels those points and can be used as an animal model to screen pathogenic bacteria from various sources.
Although being arthropod, insects have robust innate immunity and they show pathological response during infection. ${ }^{5}$ Along with short response time, another feasible feature of fifth instars silkworm larvae (SL) are large enough for ease handling in comparison to other model insects like Caenorhabditis elegance and Drosophila melanogaster. ${ }^{6}$ Silkworm does not require costly setting for rearing and easy to discard after experiments through simple autoclaving. Understanding of host-microbe's interaction and screening of microbial isolates from different sources by silkworm animal model may provide an economic tool for developing countries like Bangladesh. Using the model to survey the pathogenicity of isolated bacteria from different sources will give valuable pieces of information to understand the dynamics between microorganisms in different niches of host or environmental source and their pathogenic properties. In the present work, SL been used to establish as a robust animal model to screen pathogenic bacteria from environmental, clinical and veterinary sources. 


\section{Materials and Methods}

Bacterial Strains: Eleven bacterial strains isolated in our lab from clinical, veterinary seven and environmental samples (Table I) were used in this study. Additionally, E. coli $\mathrm{O} 157: \mathrm{H} 7$ and E. coli DH5 $\alpha$ were used as controls. A B. thuringiensis SW_R_F_ 1 strain that was isolated from flacherie diseased dead SL (our unpublished data) was also used for the present investigation.

Table I: Groupings of the different bacterial isolates and strains used in the study based on their pathogenicity screening test with their controls.

\begin{tabular}{|c|c|c|c|}
\hline Source & Organism & $\begin{array}{c}\text { NCBI } \\
\text { Genbank } \\
\text { ID } \\
\end{array}$ & $\begin{array}{l}\text { Pathogenicity } \\
\text { Group }\end{array}$ \\
\hline \multirow{4}{*}{$\begin{array}{l}\text { 1) } \\
\text { Environmental } \\
\text { Isolates (Soil } \\
\text { Samples) }\end{array}$} & Pseudomonas & KM373324 & A \\
\hline & aeruginosa SN28 & & \\
\hline & $\begin{array}{l}\text { Escherichia coli } \\
\text { SN26 }\end{array}$ & KM373319 & $\mathrm{C}$ \\
\hline & $\begin{array}{l}\text { Staphylococcus } \\
\text { aureus SN7 }\end{array}$ & KM373314 & B \\
\hline \multirow{4}{*}{$\begin{array}{l}\text { 2) Veterinary } \\
\text { Isolate (Poultry } \\
\text { Samples) }\end{array}$} & Salmonella & KF188421 & A \\
\hline & Enteritidis 56 & & \\
\hline & $\begin{array}{l}\text { Salmonella } \\
\text { Typhimurium } 77\end{array}$ & KF188422 & A \\
\hline & $\begin{array}{l}\text { Salmonella } \\
\text { Heidelberg } 53\end{array}$ & KF188420 & A \\
\hline Clinical & Pseudomonas & KM025388 & A \\
\hline \multirow{6}{*}{$\begin{array}{l}\text { Isolates } \\
\text { (from Diabetic } \\
\text { Foot Infection) }\end{array}$} & aeruginosa 47D & & \\
\hline & $\begin{array}{l}\text { Pseudomonas stutzeri } \\
\text { 54/D }\end{array}$ & KM025368 & $\mathrm{C}$ \\
\hline & $\begin{array}{l}\text { Bacillus cereus 44D } \\
\text { Swab }_{2}\end{array}$ & KM025373 & A \\
\hline & $\begin{array}{l}\text { Enterobacter sp. } \\
44 \mathrm{D} / \mathrm{MH}_{1}\end{array}$ & KM025389 & B \\
\hline & $\begin{array}{l}\text { Staphylococcus } \\
\text { aureus }\end{array}$ & NA & A \\
\hline & $\begin{array}{l}\text { 39/Diab/MH } \\
\text { Bacillus }\end{array}$ & NA & $A$ \\
\hline Pathogen & $\begin{array}{l}\text { thuringiensis } \\
\text { SW_R_F_1 }\end{array}$ & & \\
\hline 5) Laboratory & E. coli $\mathrm{DH} 5 \alpha$ & NA & $\mathrm{C}$ \\
\hline Strain & E. coli $\mathrm{O} 157: \mathrm{H} 7$ & NA & A \\
\hline
\end{tabular}

*Group A, rapid death; group B, gradual death; group C, lagged death.

Silkworm Larvae: Batches of healthy SL (Bombyx mori) were collected from Bangladesh Sericulture Research and Training Institute (BSRTI), Rajshahi during their first day after routine feeding of fresh mulberry leaves (Morus alba) in fifth instar larval state. The leaves were cleaned in water and spliced in pieces. Three different races of silkworm were used, namely Mistrari, BSR$95 / 10$ and $95 / 22 p$. Those larvae were kept in room temperature $\left(25-28^{\circ} \mathrm{C}\right)$ and $2-3$ round of feeding were provided before the commencement of further experiments.

Phenotypic and genotypic properties of bacterial strains: Hemolysin and protease tests were carried out to assess the pathogenicity of the isolates by red blood cell lysis and proteolysis respectively. 5\% sheep blood agar was used for Hemolysin as described previously eight and protease test was done on skimmed milk agar plate nine for all 11 isolates. The isolates were initially purified on nutrient agar media and a single colony was stabbed in both medium for 24 hours at $37^{\circ} \mathrm{C}$.

Eight pathogenicity specific common genes were selected to detect in different isolates (Table II). DNA of all gram negative isolates were extracted by boiled DNA extraction procedure 10 whereas gram positive organism's DNA was extracted by using bacterial DNA extraction kit (Jena Bioscience $\mathrm{GmbH}$, Germany) following manufacturer's instruction. PCR reactions were carried out using ProFlexTM 3×32-well PCR system (Applied Biosystems, USA) with G2 master-mix (GoTaq ${ }^{\circledR}$ G2 Hot Start Polymerase, Promega, USA). Reaction volume was $15 \mu 1$ in all cases. The PCR products were separated in $1 \%$ agarose gel electrophoresis and their molecular weights were detected by using $1 \mathrm{~kb}$ and $100 \mathrm{bp}$ ladder (Bioneer, Korea).

Experimental protocol: Five different treatments, such as insect pathogen $B$. thuringiensis SW_R_F_1 and human pathogen E. coli $\mathrm{O} 157: \mathrm{H} 7$; and $0.6 \%$ saline, non-pathogenic E. coli DH5 $\alpha$ strain along with no treatment control, were used to establish experimental protocol. After injecting each of the treatments using $1 \mathrm{ml} 27 \mathrm{G} 3 / 4$ " syringes into the hemolymph through dorsal surface of SL, mortality of SL was observed for 67 hours without feeding. There were 15 insects in each treatment groups. Dead SLs were detected by observing lack of their responsive movement. The data were plotted in a survival curve. ${ }^{11}$ Survival curve of different treatments were compared which illustrates the death pattern of SL that can be related with treatment injected in each group of larvae. Eleven environmental, veterinary and clinical isolates (Table I) were tested following above described method to validate the implication of SL model for the determination of pathogenicity of unknown isolates. Each treatment was done in triplicate, each comprising five larvae. A high dose of bacteria $\left(\approx 10^{9}\right.$ cells per gram of larvae) was used. 
Table II: List of pathogenic gene specific primers

\begin{tabular}{|c|c|c|c|c|c|}
\hline Pathogenic Gene & Detail & $\begin{array}{l}\text { Primer } \\
\text { Name }\end{array}$ & Sequence (5'-3') & $\begin{array}{l}\text { Amplicon } \\
\text { Size } \\
\text { (bp) }\end{array}$ & $\mathbf{T}_{\mathrm{m}}\left({ }^{\circ} \mathbf{C}\right)$ \\
\hline hblA (Das et al., 2009) & $\begin{array}{c}\text { Hemolysin } \\
\text { BL }\end{array}$ & HblA1 & GCTAATGTAGTTTCACCTGTAGCAAC & 834 & 58 \\
\hline $\begin{array}{l}\text { hlyA (Wang et al., } \\
\text { 1997) }\end{array}$ & $\begin{array}{l}\text { O Antigen } \\
\text { Gene }\end{array}$ & $\begin{array}{l}\mathrm{Hb} 1 \mathrm{~A} 2 \\
\mathrm{O} 157-3\end{array}$ & $\begin{array}{l}\text { AATCATGCCACTGCGTGGACATATAA } \\
\text { GTA GGG AAG CGA ACA GAG }\end{array}$ & 361 & 52 \\
\hline stx 1 (Rasheed, 2014) & $\begin{array}{l}\text { Shiga toxin } \\
\text { group } 1\end{array}$ & $\begin{array}{l}\text { O157-4 } \\
\text { Stx1-F }\end{array}$ & $\begin{array}{l}\text { AAGCTCCGTGTGCCTGAA } \\
\text { ACACTGGATGATCTCAGT GG }\end{array}$ & 614 & 60 \\
\hline ssaT (Deekshit, 2013 ) & $\begin{array}{l}\text { Secretion } \\
\text { system } \\
\text { apparatus }\end{array}$ & $\begin{array}{l}\text { Stx1-R } \\
\text { ssaT-F }\end{array}$ & $\begin{array}{l}\text { CTGAATCCCCCTCCATTATG } \\
\text { ATGCGCAAATAATGGTTGAT }\end{array}$ & 780 & 55 \\
\hline cna (Switalski, 1993 ) & $\begin{array}{c}\text { Collagen } \\
\text { adhesion } \\
\text { encoding } \\
\text { gene }\end{array}$ & $\begin{array}{l}\text { ssaT-R } \\
\text { cna-F }\end{array}$ & $\begin{array}{l}\text { TCAGGCGCGTTAACAGGACG } \\
\text { AGTGGTTACTAATACTG }\end{array}$ & 744 & 55 \\
\hline hlg (Switalski, 1993 ) & $\begin{array}{c}\text { Gamma } \\
\text { hemolysin }\end{array}$ & $\begin{array}{l}\text { cna-R } \\
\text { hlg-F }\end{array}$ & $\begin{array}{l}\text { ATTTGGTTAGATAGGAC } \\
\text { GCCAATCCGTTATTAGAAAATGC }\end{array}$ & 937 & 55 \\
\hline oprL (De Vos, 1997 ) & $\begin{array}{l}\text { Outer } \\
\text { membrane } \\
\text { protein }\end{array}$ & $\begin{array}{l}\text { hlg-R } \\
\text { oprL-F }\end{array}$ & $\begin{array}{l}\text { TAGGCAACGATGCAGATACC } \\
\text { ATGGAAATGCTGAAATTCGGC }\end{array}$ & 504 & 57 \\
\hline toxA (De Vos, 1997 ) & Exotoxin A & $\begin{array}{l}\text { oprL-R } \\
\text { toxA-F } \\
\text { toxA-R }\end{array}$ & $\begin{array}{l}\text { CTTCTTCAGCTCGACGCGACG } \\
\text { GACAACGCCCTCAGCATCACCAGC } \\
\text { CGCTGGCCCATTCGCTCCAGCGCT }\end{array}$ & 396 & 68 \\
\hline
\end{tabular}

The data was observed for 44 hours and plotted in a survival curve ${ }^{12}$ and each treatment was compared with control conditions.

Postmortem identification of pathogenic bacteria: After collecting dead caterpillar from different treatment groups, their bodies were cut into pieces by sterile scissor, resuscitated in alkaline peptone water followed by culture in selective media such as mannitol salt agar, bismuth sulfite agar and ceramide which are used for the isolation of Staphylococcus, Salmonella and Pseudomonas respectively. ${ }^{13}$ Antibiogram of both bacterial culture from original treatment and culture after bacterial isolation from dead larvae of different treatments was done. The bacterial culture equivalent to $0.5 \mathrm{McF}$ arland solution ${ }^{14}$ was spread with cotton swab on Muller-Hinton agar. After 30 minutes of incubation in room temperature, different antibiotic disks (Table III) was placed on the solid medium and resistance pattern of all bacteria observed after 24-hour incubation at $37^{\circ} \mathrm{C}$.

Determination of $L D_{50}$ : Median lethal dose (LD 50 ) was determined for $P$. aeruginosa $47 \mathrm{D}$, a clinical isolate and Salmonella sp. 77, a veterinary isolate along with positive control $E$. coli O157:H7 and negative control E. coli DH5a. A series of dilution of test isolates $\left(10^{8}, 10^{7}, 10^{6}\right.$ and $10^{5} \mathrm{cells} / \mathrm{gram} /$ dose) were prepared and injected into SL through dorsal surface into hemolymph along with control treatments of high doses $\left(10^{8}\right.$ cells/gram/dose).

Table III: The antibiogram pattern of original culture and culture isolated from dead $\mathrm{SL}^{*}$

\begin{tabular}{|c|c|c|c|c|}
\hline \multirow[t]{2}{*}{ Treatments } & \multicolumn{2}{|c|}{ Original Culture } & \multicolumn{2}{|c|}{$\begin{array}{c}\text { Culture Isolated from } \\
\text { Dead SL }\end{array}$} \\
\hline & Resistant & Sensitive & Resistant & Sensitive \\
\hline $\begin{array}{l}\text { Pseudomonas } \\
\text { aeruginosa } \\
\text { 47D }\end{array}$ & AM, C & $\begin{array}{l}\text { AZM, } \\
\text { CIP }\end{array}$ & $\mathrm{AM}, \mathrm{C}$ & AZM,CIP \\
\hline $\begin{array}{l}\text { Salmonella } \\
\text { Typhimurium } \\
\text { isolate } 77\end{array}$ & LEV, VA & IMI & LEV,VA & IMI \\
\hline $\begin{array}{l}\text { Bacillus cereus } \\
\text { 44D Swab }\end{array}$ & PB & IMI, CIP & PB & CIP, IMI \\
\hline $\begin{array}{l}\text { Pseudomonas } \\
\text { aeruginosa } \\
\text { 47D }\end{array}$ & $\mathrm{C}, \mathrm{CL}$, & $\begin{array}{l}\text { AZM, } \\
\text { CIP }\end{array}$ & $\mathrm{C}, \mathrm{CL}$, & $\begin{array}{l}\text { AZM, } \\
\text { CIP }\end{array}$ \\
\hline $\begin{array}{l}\text { Salmonella. } \\
\text { Heidelberg } \\
\text { isolate } 53\end{array}$ & LEV, TE & IMI & LEV, TE, & IMI \\
\hline $\begin{array}{l}\text { Staphylococcus } \\
\text { aureus } \\
\text { 39/Diab/MH }\end{array}$ & $\mathrm{DO}, \mathrm{AM}$ & $\begin{array}{l}\text { CIP, IMI, } \\
\text { AZM }\end{array}$ & $\begin{array}{l}\text { CIP, AM, } \\
\text { DO }\end{array}$ & $\begin{array}{l}\text { IMI, } \\
\text { AZM }\end{array}$ \\
\hline
\end{tabular}

* Abbreviation of antibiotic is following: AM (Ampicillin), C (Chloramphenicol), AZM (Azithromycin), CIP (Ciprofloxacin), LEV (Levofloxacin), VA (Vancomycin), IMI (Imipenum), PB (Polymyxin B), CL (Cephalexin), AZM (Azithromycin), TE (Tetracycline), DO(Doxycycline) 
By plotting percentage of dead larvae against a range of doses in defined time and fitting the data in 2-degree polynomial regression model, LD50 was determined by calculating the dose which represents $50 \%$ reduction of live SL. ${ }^{15}$ The generalized polynomial equation of two degree fitted with the experimental data is:

$y=\beta_{0}+\beta_{1} x+\beta_{2} x^{2}+\varepsilon \ldots \ldots \ldots[1]$

Here, $\beta_{0}, \beta_{1}, \beta_{2}$ are parametric estimation of $x$, $x$ is independent variable $(\log (\operatorname{dose}))$, y (\% of dead $\mathrm{SL}$ ) is dependent variable and $\varepsilon$ is estimated error of the fit. The statistical analysis and $\mathrm{LD}_{50}$ determination were carried out on $\mathrm{R}$ (version 3.0.1) using ggplot2 package. ${ }^{16,17}$

\section{Results}

Silkworm larvae act well as animal model for pathogen detection: After plotting percentage of survival data of silkworm from control treatments showed distinct survival pattern. B. thuringiensis SW_R_F_1 caused a sharp death and E. coli O157:H7 caused a continuous death with time which is indicated by a decline in number of live silkworm. In contrast, no treatment, $0.6 \%$ saline condition and E. coli DH5 $\alpha$ caused an initially lagged reduction of live silkworm larvae number. By comparing survival curve of twelve challenged isolates with control treatment, their pathogenicity was deduced and categorized into three groups (Table I) - highly pathogenic (sharp decline), pathogenic (continuous decline) and nonpathogenic (lagged decline) (Fig. 1).

Post-mortem identification of pathogens confirms infections: Growth of bacteria which were isolated from dead silkworm of treatment group A (Table I), observed on respective selective media for $P$. aeruginosa 47D, $P$. aeruginosa SN28, $S$. aureus 39/Diab/MH1, Salmonella Enteritidis 56, Salmonella Typhimurium 77 and Salmonella Heidelberg 53. The antibiogram pattern of original culture and culture isolated from dead silkworm larvae of different treatments was observed and the antibiogram profile was delineated (Table II). The antibiogram pattern of all of the bacteria isolated from dead silkworm larvae of different pathogenic treatment showed similarity with that of the original culture, except for Staphylococcus aureus 39/Diab/MH1, in which ciprofloxacin was resistant in post-mortal isolate but sensitive in original culture.

Phenotypic and genotypic properties of the pathogens corroborate the model: In blood agar plates, $\beta$ hemolysin was observed for Pseudomonas aeruginosa 47D, Bacillus cereus 44D Swab2 and Staphylococcus aureus 39/Diab/MH1. All Salmonella spp. showed $\alpha$ hemolysin in blood agar plates. In protease test Bacillus cereus 44D Swab2 produced a clear zone and Pseudomonas aeruginosa 47D produced hazy yellow zone around it. PCR was done with pathogenicity associated gene for detection of pathogenicity. Outer membrane protein gene oprL (504 bp) and exotoxin A gene toxA (396 bp) were positive in both Pseudomonas aeruginosa 47D, a clinical isolate and Pseudomonas aeruginosa SN28, an environmental isolate (Fig. 2(a)). Hemolysin A gene, hlyA (361 bp) was detected in E. coli $\mathrm{O} 157: \mathrm{H} 7$. Secretion system apparatus protein gene, $s s a \mathrm{~T}$, which is a pathogenicity island II specific gene for Salmonella, was screened positive in all Salmonella strains at 780 base pair position (Fig. 2(b)).

$L D_{50}$ determination: For $P$. aeruginosa $47 \mathrm{D}$, change in percentage of dead silkworm larvae across a range of varying logarithm of doses were fitted by polynomial regression model for data points at 12, 18, 24 and 34 hours (Fig. 3.a). For Salmonella sp. Isolate 77, this was done for data points at 24, 34, 40 and 46 hours (Fig. 3.b). For $P$. aeruginosa 47D, the 12-hour model and for Salmonella sp. 77 both 12 and 40-hour model were found to be statistically significant at $90 \%$ confidence intervals (Table IV).

Table IV: Summary statistics of significant polynomial model fitted in $\mathrm{LD}_{50}$ plot. Here, $\beta_{0}$ is estimate of intercept of fitted regression curve; $\beta_{1}, \beta_{2}, \beta_{3}$ are parametric estimates of $x, x^{2}$ and $x^{3}$ respectively; and $\varepsilon$ is the estimate of standard error in the model (equation 1).

\begin{tabular}{|c|c|c|c|c|c|c|}
\hline \multirow{2}{*}{$\begin{array}{l}\text { Dose-Death } \\
\text { Regression } \\
\text { Model }\end{array}$} & \multicolumn{3}{|c|}{$\begin{array}{l}\text { Estimates of } \\
\text { Parameter }\end{array}$} & \multirow{2}{*}{$\begin{array}{l}\text { Residual } \\
\text { S.E. }\end{array}$} & \multirow{2}{*}{$\underset{\mathrm{R}^{2}}{\operatorname{Adj}}$} & \multirow{2}{*}{$\mathrm{p}$} \\
\hline & $\beta_{0}$ & $\beta_{1}$ & $\beta_{2}$ & & & \\
\hline $\begin{array}{c}P . \text { aeruginosa } 47 \mathrm{D} \\
(12 \text { Hour })\end{array}$ & 30 & 60.5 & 27.05 & 2.91 & 0.99 & 0.04 \\
\hline $\begin{array}{c}\text { Salmonella sp. } \\
\text { Isolate } 77 \text { (24 Hour) }\end{array}$ & 27 & 69.81 & -2.54 & 4.21 & 0.99 & 0.06 \\
\hline $\begin{array}{c}\text { Salmonella } \text { sp. } \\
\text { Isolate } 77 \text { (40 Hour) }\end{array}$ & 32 & 63.99 & -2.27 & 4.28 & 0.99 & 0.07 \\
\hline
\end{tabular}

From the fitted curve of those models, $\mathrm{LD}_{50}$ determined by finding $\log ($ dose $)$ value in $\mathrm{x}$-axis which correspond $50 \%$ dead silkworm number in y-axis. Calculated $\mathrm{LD}_{50}$ was $4.63 \times 10^{7}, 8.02 \times 10^{7}$ 
and $6.83 \times 10^{7} \quad$ cells $/ 100 \mu 1 /$ gram respectively (Table V).

Table V: Calculation of $\mathrm{LD}_{50}$

\begin{tabular}{|c|c|c|}
\hline $\begin{array}{c}\text { Dose-Death Regression } \\
\text { Model }\end{array}$ & $\begin{array}{c}\log (\mathrm{x}) \text { at } \\
\mathrm{Y}=50 \%\end{array}$ & $\mathrm{LD}_{50}$ \\
\hline P. aeruginosa 47D (12 Hour) & 17.65 & $4.63 \times 10^{7}$ \\
\hline $\begin{array}{l}\text { Salmonella Isolate } 77 \text { (24 } \\
\text { Hour) }\end{array}$ & 18.20 & $8.02 \times 10^{7}$ \\
\hline $\begin{array}{l}\text { Salmonella Isolate } 77 \text { (40 } \\
\text { Hour) }\end{array}$ & 18.04 & $6.83 \times 10^{7}$ \\
\hline
\end{tabular}

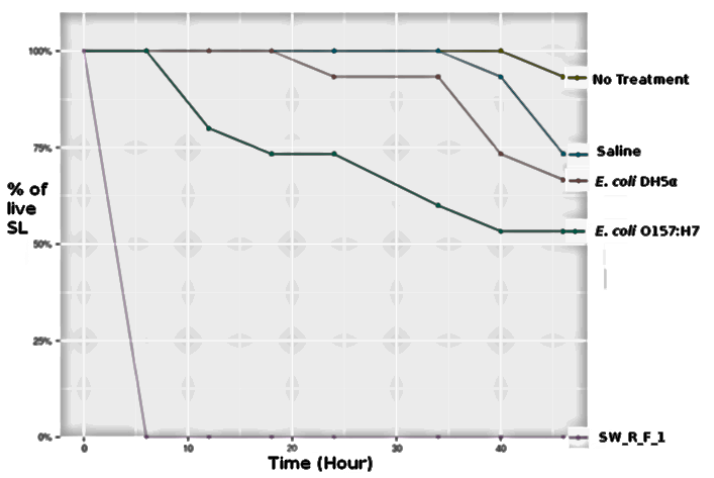

Fig. 1: Establishment of experimental control. Bacillus thuringiensis SW_R_F_1 causing a steep death, E. coli O157:H7 causing a continuous death while E. coli DH5 $\alpha$, saline and no treatment condition caused lagged death.

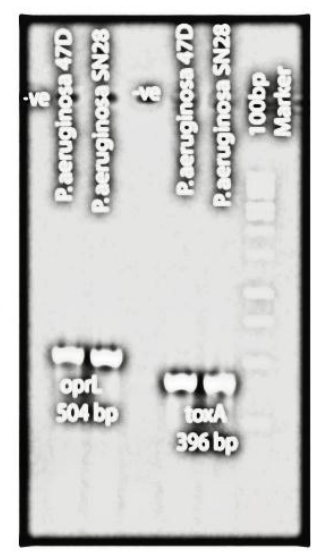

(a)

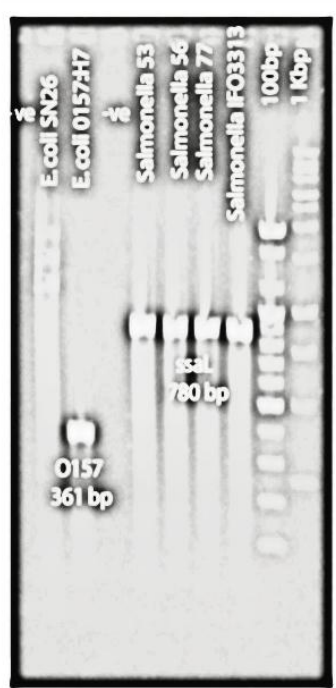

(b)
Fig. 2: Molecular detection of pathogenicity associated genes; (a) showing oprL in 504 bp and tox A in 396 bp position, (b) showing $\mathrm{O} 157$ in $361 \mathrm{bp}$ and ssaL in $780 \mathrm{bp}$

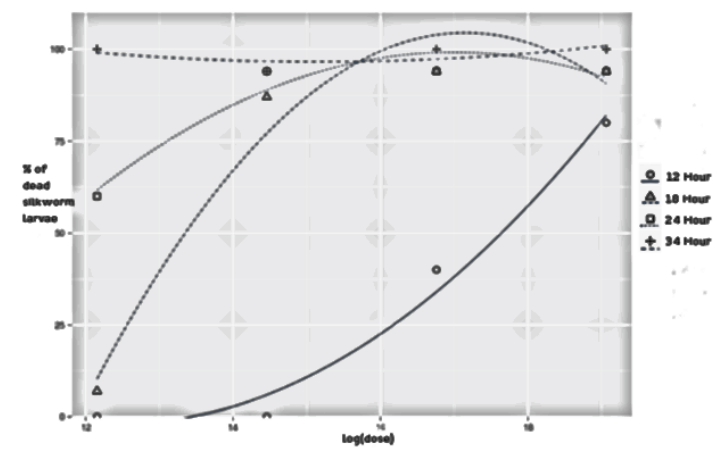

(a)

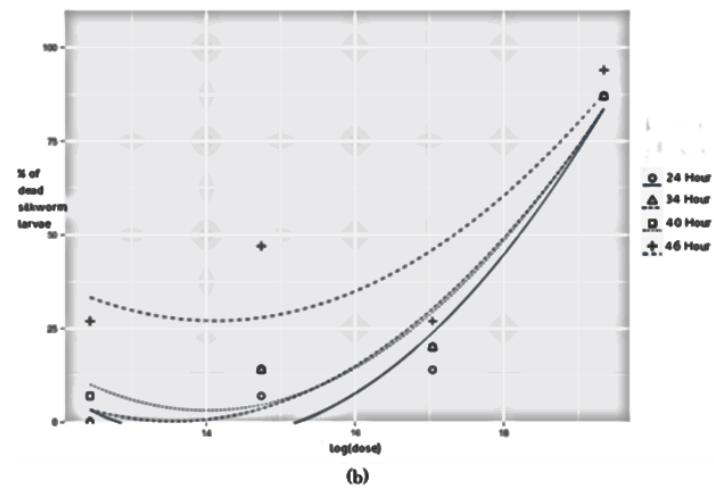

Fig. 3: $\mathrm{LD}_{50}$ determination for P. aeruginosa 47D (a) and Salmonella sp. 77 (b). With increasing dose, percentage of dead SL increased. Four curves were fitted in polynomial regression model for each organism for four different time and statistically significant fitted curve was used to calculate $\mathrm{LD}_{50}$.

\section{Discussion}

The target of this study was to develop a rapid protocol to screen a large number of bacterial isolates from different sources. Advent of new technology has instrumented scientists in a way that they confront a large number microorganism of new species or strains, many of which are previously uncharacterized or poorly characterized. So, it is often required to characterize their pathogenicity. Although mice are a well establish animal model to test pathogenicity, it would be a hassle to use it for screening large number of isolates such as handling many mice, cost, rearing space and consideration ethical issues concerning killing of mammals in large number. In contrast, silkworm does not have those constrains and therefore can be a robust solution for screening problem.

E. coli DH5a, E. coli O157:H7, Bacillus thuringiensis SW_R_F_1 and $0.6 \%$ saline were used to establish experimental control along with a group of silkworm larvae with no treatment 
conditions. Their survival curve indicates that $B$. thuringiensis SW_R_F_1 and E. coli O157:H7, which are pathogenic to silkworm and human respectively, while used as positive control in this work caused a continuous fall of live silkworm larvae number after challenge dose. Negative treatment condition showed a decline after an initial plateau period. This distinctive trend between positive and negative control set the ground on which inference can be drawn about the pathogenicity of test isolates. Previously other studies also established experimental condition using human pathogen $S$. aureus five or silkworm pathogen nuclear polyhedrons virus ${ }^{18}$ as positive control. A limitation of current work is that $\mathrm{LD}_{50}$ is remained undetermined for control treatment conditions. But the experimental condition established here remains feasible for screening experiments.

Eleven bacterial isolates from three different sources were screened in silkworm larvae insect model and their pathogenicity was inferred by comparing survival curve of each test treatment with control. Previously, silkworm was used to evaluate pathogenicity of bacteria attached to cedar pollen. ${ }^{12}$ In this experiment, silkworm has been used to screen out pathogenic bacterium from a wide variety of sources. The insect model described in this work clearly identifies Salmonella Typhimurium isolate $77, \quad P$. aeruginosa 47D, S. aureus 39/Diab/MH1, Bacillus cereus 44D Swab2, P. aeruginosa SN28, Salmonella Enteritidis isolate 56, Salmonella Heidelberg isolate 53, S. aureus SN7, Enterobacter sp. 44D/MH1, as pathogens despite of their sources.

Also, test bacteria under study were isolated from dead larvae, detected by growing in selective media and their antibiotic pattern was compared with original culture. In all cases, except $S$. aureus 39/Diab/MH1, the antibiotic resistance pattern was identical. This confirms that in most treatment conditions death of silkworm was caused by the infection by injected bacterium. The difference in antibiogram pattern for $S$. aureus 39/Diab/MH1 before and after post-mortem samples might be due to contamination during handling or preparation or the inoculated bacterium might have gained its' resistance gene after injection by horizontal gene transfer. Salmonella Typhimurium 77, a veterinary pathogen isolated from poultry and a clinical isolate $P$. aeruginosa 47D were selected for $\mathrm{LD}_{50}$ determination. The $\mathrm{LD}_{50}$ for $P$. aeruginosa $47 \mathrm{D}$ was $4.63 \times 10^{7}$ cells per 100 cells $/ 100 \mu 1 /$ gram in 12 hours and for Salmonella Typhimurium 77, it was $8.02 \times 10^{7}$ cells $/ 100 \mu 1 /$ gram for 24 hours. For P. aeruginosa, similar $\mathrm{LD}_{50}\left(\approx 10^{6}\right.$ cells per dose in OEP vaccination and $\approx 10^{8}-10^{9}$ cells in three component vaccination) was observed in immunized rat, but not in non-immunized rat $\left(\approx 10^{3}-10^{4}\right.$ cells $){ }^{19}$ The same scenario was observed in case of Salmonella Typhimurimu $77 .^{20}$ The higher LD50 of gram negative organism in insect model previously was correlated with 60fold increase of expression of C-reactive protein $(\mathrm{CRP}){ }^{21}$

The putative 10 pathogens (from group A and B in Table I) were also characterized as pathogens by the presence of four specific genes responsible for pathogenicity and two biochemical properties. These biochemical tests were used to identify novel pathogenic genes five-inch silkworm infection model. Among the test isolates, Bacillus cereus 44D Swab2, P. aeruginosa 47D and $S$. aureus 39/Diab/MH1 showed protease positive test and produced zone of lysis in sheep blood agar. It should be noted that these two properties had been recognized as biochemical properties of a pathogen five. To detect pathogenicity associated genes, in $P$. aeruginosa 47D and $P$. aeruginosa $\mathrm{N} 28$ isolate, outer membrane protein gene oprL and exotoxin $\mathrm{A}$ gene tox $\mathrm{A}$ were detected by PCR. Hemolysin A gene, hlyA was detected in E. coli $\mathrm{O} 157: \mathrm{H} 7$ which was positive control in this work. Secretion system apparatus protein gene, ssaT, which is a pathogenicity island II specific gene for Salmonella, found in all Salmonella strains used in this study (e.g. Salmonella sp. Enteritidis isolate 56, $S$. Typhimurium isolate $77, S$. Heidelberg isolate 53). The biochemical properties and molecular characterization of pathogenic genes detected in 10 putative pathogens identified by silkworm larvae model corroborated the authenticity and effectiveness of the insect larvae model as a method of detection of pathogens isolated from various sources. Only a small set of pathogenic gene and phenotypic characteristics was investigated, so negative results in these experiment does not necessarily conclude to lack of virulence of the isolates. Therefore, the informality, sensitivity and specificity of this 
model are yet to be determined, and further more scrutinized experiments are required. It could be concluded that the minimal experimental timelength requirement, cost effectiveness, less space required for large number pathogen handling and the robustness of the insect model potentially excursing the model as an effective alternative method to animal model for pathogenicity detection for bacteria of different sources. The findings revealed that (i) Silkworm, B. mori, larvae may be used as an effective and authentic model for pathogen detection; (ii) The method is cost-effective, less time consuming, needs less space and robust.

Conclusion: This work presents a study of silkworm with conclusion that this insect can be used as a feasible animal model to screen pathogens of wide range of origin simultaneously. Silkworm insect model can also help to classify the level of pathogenicity of screened pathogens. $\mathrm{LD}_{50}$ of different pathogen in this model can provide a quantitative way to compare this model with another higher animal.

\section{Authorship Statement}

Arafat Rahman has carried out all wet-lab experiments and data analysis. Md. Aftab Uddin contributed on SL rearing and supply. Munawar Sultana and M. Abdul Malek take part on study design result interpretation. M Anwar Hossain take part in developing hypothesis and concept, design of experiment and finalization of the manuscript. Everyone has taken part in this article writing process and approved the manuscript.

\section{Acknowledgements}

In this work $\mathrm{M}$ Anwar Hossain and Arafat Rahman received support from the National Science and Technology (NST) project grant and fellowship of Ministry of Science and Technology, Bangladesh Government respectively. We also acknowledge the kind support of Bangladesh Sericulture Research and Training Institute, Rajshahi, particularly Md. Munsur Ali, research officer of the institute.

\section{References}

1. Chakraborty C HCH, C. H.; Wen, Z. H.; Lin, C. S.; Agora moorthy, G. Zebrafish: a complete animal model for in vivo drug discovery and development. Current Drug Metabolism 2009;10(2):116-24.

2. Kari GR, U.; Dicker, A. P. Zebrafish: an emerging model system for human disease and drug discovery. Clin Pharmacol Ther. 2007;82(1):70-80.

3. Schlaberg R, KE Simmon, MA Fisher. A systematic approach for discovering novel, clinically relevant bacteria. Emerg Infect Dis. 2012;18(3):422-30.

4. Kostic AD, MR Howitt, WS Garrett. Exploring hostmicrobiota interactions in animal models and humans. Genes Dev. 2013;27(7):701-18.

5. Kaito C, K Kurokawa, Y Matsumoto, Y Terao, S Kawabata, S Hamada, K Sekimizu. Silkworm pathogenic bacteria infection model for identification of novel virulence genes. Mol Microbiol. 2005;56(4):934-44.

6. Hamamoto H. TA, Narushima K., Horie R., Sekimizu K. Silkworm as a model animal to evaluate drug candidate toxicity and metabolism. Comp Biochem Physiol. 2009; 149:334-39.

7. Sultana M, R Bilkis, F Diba, M A. Hossain. Predominance of Multidrug Resistant Zoonotic Salmonella Enteritidis Genotypes in Poultry of Bangladesh. The Journal of Poultry Science. 2014.

8. Gerhardt P. Methods for general and molecular bacteriology: American Society for Microbiology; 1994. 619, 42, $47 \mathrm{p}$.

9. Mosca CO, MD Moragues, J Llovo, A Al Mosaid, DC Coleman, J Pontón. Casein agar: a useful medium for differentiating Candida dubliniensis from Candida albicans. J Clin Microbiol. 2003;41(3):1259-62.

10. Silva GAd, TL Bernardi, PDC Schaker, M Menegotto, P Valente. Rapid yeast DNA extraction by boiling and freeze-thawing without using chemical reagents and DNA purification. Brazilian Archives of Biology and Technology. 2012;55(2):319-27.

11. Yuan Hu HH, Kazuhisa Sekimizu. Drug Discoveries \& Therapeutics Use of silkworms to evaluate the pathogenicity of bacteria attached to cedar pollen 2013;7(4):153-57.

12. Yuan Hu HH, Kazuhisa Sekimizu. Use of silkworms to evaluate the pathogenicity of bacteria attached to cedar pollen. Drug Discov Ther. 2013;7(4):153-57. 
13. Atlas RM, JW Snyder. Handbook of Media for Clinical and Public Health Microbiology: Taylor \& Francis; 2013.

14. McFarland J. The nephelometer: an instrument for estimating the number of bacteria in suspensions used for calculating the opsonic index and for vaccines. J Am Med Assoc. 1907;49(14):1176-78.

15. Heng-Ping Tao Z-YS, Feng Zhu, Xiao-Fang Xu, XuDong Tang, Li Xu Isolation and Identification of a Pathogen of Silkworm Bombyx mori. Curr Microbiol. 2011; 62:876-83.

16. Team RC. R: A language and environment for statistical computing. R Foundation for Statistical Computing, 2013 Vienna, Austria. ISBN 3-90005107-0, URL http://www. R-project. org; 2013.

17. Wickham H. ggplot2: elegant graphics for data analysis: Springer Science \& Business Media; 2009.
18. Venkatesh Kumar R. AS. In vivo therapeutic effects of antibacterial and antiviral antibiotics using Bombyx mori L. as an animal model. Journal of Medicinal Plants Research. 2011;5(14):3118-21.

19. Homma JY, Abe, C., Tanamoto, K., Hirao, Y., Morihara, K., Tsuzuki, H., Ishihara, T. Effectiveness of immunization with single and multi-component vaccines prepared from a common antigen (OEP), protease and elastase toxoids of Pseudomonas aeruginosa on protection against hemorrhagic pneumonia in mink due to $\mathrm{P}$. Aeruginosa The Japanese journal of experimental medicine. 1978;48(2):111-33.

20. Zhang X, Kelly, S. M., Bollen, W. S., Curtiss, R., Characterization and immunogenicity of Salmonella typhimurium SL1344 and UK-1 delta crp and delta cdt deletion mutants. Infect Immun. 1997;65(12): 5381-87.

21. Ng PM, Z Jin, SS Tan, B Ho, JL Ding. C-reactive protein: a predominant LPS-binding acute phase protein responsive to Pseudomonas infection. J Endotoxin Res. 2004;10(3):163-74. 